\title{
Valve selection in aortic valve endocarditis
}

\author{
Sossio Perrotta, Yana Zubrytska \\ Department of Cardiothoracic Surgery, Sahlgrenska University Hospital, Gothenburg, Sweden \\ Kardiochirurgia i Torakochirurgia Polska 2016; 13 (3): 203-209
}

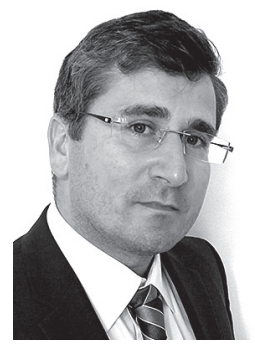

\begin{abstract}
Aortic prosthetic valve endocarditis (PVE) is a potentially lifethreatening disease. Mortality and incidence of infective endocarditis have been reduced in the past 30 years. Medical treatment of aortic PVE may be successful in patients who have a prompt response after antibiotic treatment and who do not have prosthetic dysfunction. In advanced stages, antibiotic therapy alone is insufficient to control the disease, and surgical intervention is necessary. Surgical treatment may be lifesaving, but it is still associated with considerable morbidity and mortality. The aim of surgery is to perform a radical excision of all infected and necrotic tissue, reconstruction of the left ventricle outflow tract, and replacement of the aortic valve. There is no unanimous consensus on which is the optimal prosthesis to implant in this context, and several surgical techniques have been suggested. We aim to analyze the efficacy of the surgical treatment and discuss the issue of valve selection in patients with aortic valve endocarditis.
\end{abstract}

Key words: aortic valve endocarditis, surgery, infective endocarditis.

\section{Introduction}

Prosthetic aortic valves are a risk factor for infective endocarditis (IE), and prosthetic valve endocarditis (PVE) remains potentially a life-threatening disease. Prosthetic valve endocarditis can be diagnosed in about $1 \%$ to $6 \%$ of patients with valve prostheses [1]. In selected cases, cure by medical treatment can be achieved in patients with PVE [2]. Patients diagnosed early in the course of the disease, patients with a prompt antibiotic response or with streptococcal disease, and patients with echocardiographic findings such as small or absent vegetations, no severe prosthetic dysfunction, and no periprosthetic tissue damage, are candidates for conservative management.

In advanced stages, however, antibiotic therapy alone is insufficient to control the disease [3], and surgical intervention is necessary. Surgery is required in patients with heart failure or cardiogenic shock caused by valvular dysfunction.

\section{Streszczenie}

Zapalenie wsierdzia na sztucznej zastawce aortalnej (PVE) jest chorobą zagrażającą życiu pacjenta. Wskaźniki śmiertelności i zapadalności infekcyjnego zapalenia wsierdzia zmniejszyły się w ciągu ostatnich 30 lat. Terapia aortalnego PVE może być skuteczna u pacjentów bez dysfunkcji protezy, u których następuje szybka odpowiedź na antybiotykoterapię. W zaawansowanym stadium choroby antybiotykoterapia nie wystarcza do jej opanowania i potrzebna jest interwencja chirurgiczna. Leczenie chirurgiczne może uratować życie pacjenta, jednak wiąże się ze znaczną chorobowością i śmiertelnością. Celem chirurgii jest wykonanie radykalnego wycięcia całej zainfekowanej i nekrotycznej tkanki, rekonstrukcja drogi odpływu lewej komory oraz wymiana zastawki aortalnej. Nie ma konsensusu dotyczącego optymalnej protezy, którą należałoby wszczepić w takiej sytuacji; sugeruje się też stosowanie kilku technik chirurgicznych. Naszym celem była analiza skuteczności leczenia chirurgicznego oraz omówienie doboru zastawki u pacjentów z zapaleniem wsierdzia na zastawce aortalnej.

Stowa kluczowe: zapalenie wsierdzia na zastawce aortalnej, chirurgia, infekcyjne zapalenie wsierdzia.

Surgery should also be undertaken in hemodynamically stable patients with abscess, recurrent emboli despite appropriate antibiotic therapy, aggressive infection resistant to antibiotic therapy, and fungal endocarditis [4]. Surgical therapy involves excision of all infected and necrotic tissue, drainage of abscesses, closure of fistulas, and complete removal of prosthetic material, replacement of the aortic valve and reconstruction or replacement of the aortic root. The surgical operation extends from only removal and replacement of the infected aortic prostheses to a more complex situation with radical resection and replacement of the aortic root, the outflow tract, and even the ascending aorta. Even with aggressive surgical therapy, the infection may be difficult to eradicate, and mortality and morbidity remain high [4]. The optimal type of aortic prosthesis for patients with PVE remains unclear; different prosthetic valves are used and different surgical techniques are applied in this group of patients [5-15].

Address for correspondence: Sossio Perrotta MD, Department of Cardiothoracic Surgery, Sahlgrenska University Hospital, 41345 Gothenburg, Sweden, phone: +46 737238120, e-mail: perrottasossio@yahoo.com

Received: 18.06.2016, accepted: 18.08.2016. 
In this article, we analyzed, through a literature review, the efficacy of the surgical treatment and the issue of valve selection in patients with aortic valve endocarditis.

\section{Material and methods \\ Literature search}

A computerized search of the English-published literature was conducted on the Medline database. The selected articles were reviewed by the authors and judged on their relevant contribution to the subject of this study.

\section{Search strategy}

The literature was reviewed primarily by searching the Medline database from 1946 to November 2013 using the OVID interface ( ${ }^{\star}$ Endocarditis/di, su, th OR aortic valve endocarditis.mp. OR prosthetic aortic valve endocarditis.mp.)

\section{Search outcome}

The following steps were performed: identification of titles through a database search, removal of duplicates, screening of abstracts, assessment of full-text articles for eligibility, and final inclusion in the study. A total of 1479 reports were found in the Medline database, of which 40 were included in this review.

\section{Inclusion criteria}

Studies concerning aortic PVE were selected for analysis. The inclusion criteria were: full text papers that reported the surgical treatment, the post-operative mortality, need for reoperation due to reinfection, midterm or longterm follow-up.

\section{Discussion}

Endocarditis of a native aortic valve, and especially of a prosthetic aortic valve, is an uncommon disease with an incidence of $0.3-1.2 \%$ per patient per year, while the prevalence varies in different studies between $1 \%$ and $6 \%$ [1]. A limited extent of retrospective and very few prospective reports are published in the literature, and a comparison of the outcomes is difficult because most series contain heterogeneous patient populations: patients with both prosthetic and native valve endocarditis, both mitral and aortic valve endocarditis, and both healed and active endocarditis. Often, the patients are collected over a long period of time and were operated on by several surgeons through different surgical techniques; sometimes the patients are from several hospitals. These factors could present a limitation in making a definitive judgment on this specific clinical scenario.

\section{Pathophysiology}

Prosthetic valve endocarditis represents $10-30 \%$ of cases of IE in most developed countries [4]. The risk of earlyonset endocarditis is greater for mechanical heart valves, but later after implantation, the incidence becomes similar for mechanical prostheses and bioprostheses [4]. Gram- positive organisms are the main etiologic agents in endocarditis of the aortic valve. Microorganisms of the genus Streptococcus are primarily detected in cases of native aortic valve endocarditis $[5,10]$, whereas agents of the genus Staphylococcus are identified in patients with PVE $[5,10]$ and are associated with a poor prognosis [4]. Staphylococcus has the ability to adhere on prosthetic devices, start biofilm production, and secrete exoenzymes [16]. Once attachment of the bacteria has been achieved, an extracellular polysaccharide matrix is produced, which engulfs the bacteria and then works as a barrier to antibacterial access and may inhibit host defenses [16].

\section{Graft selection in aortic valve endocarditis}

The optimal type of aortic prosthesis for patients with IE remains unclear. The general consensus clearly tends toward the use of biological material rather than prosthetic devices for surgical repair in the presence of infection $[5,6,17]$.

\section{Aortic homograft}

Many authors consider the aortic homograft as the gold standard in the treatment of aortic valve endocarditis. Several reports have suggested the use of an aortic homograft in IE [5, 6, 17-23] (Tab. I). Sabik et al. [6] and Musci et al. [20] reported on the largest series of patients with PVE who have undergone homograft implantation, while the majority of the authors reported on much smaller series of patients and included both patients with native and those with prosthetic valve endocarditis. The reported 30 -day mortality ranges between $3.9 \%$ and $25 \%$ in patients with PVE $[6,20]$ and $3 \%$ and $16 \%$ in patients with native valve endocarditis (NVE) $[19,20]$, showing a better outcome for patients with NVE. In addition, the survival at 1, 5 and 10 years is better for patients operated on for NVE than for those with PVE $[5,20]$, indicating that patients with PVE have worse survival than those with native endocarditis.

Long-term survival at 1 year in patients with PVE ranges between 67\% and 92\% [20, 21]. However, if we look at those authors who report only on PVE, 1-year survival is better, ranging from $81 \%$ to $92 \%[21,23]$. The same difference can be observed for the survival at 5 years, which ranges from $48 \%$ to $85 \%[20,22]$ in mixed series, while it ranges from $70 \%$ to $85 \%[5,22]$ in selected series. Late mortality is not due to recurrent infection or valve dysfunction, but it seemed to be related to the patients' bad clinical condition.

The reinfection incidence in aortic homograft replacement is low, ranging from 0 to $6.8 \%$ in the majority of the studies $[5,6,20,24]$, but higher incidence has been reported [25]. Some studies report a higher incidence of recurrent endocarditis in patients treated with mechanical or biological valve prostheses than in patients treated with a homograft [24], while other authors report no difference in the rate of recurrent infection between patients who received a homograft and those who received a conventional prosthesis $[10,25,26]$. The low incidence of early and late recurrent infection reported is mainly the result of early diagnosis, aggressive surgical management, including com- 
Tab. I. Outcome of patients with aortic valve endocarditis treated with implantation of an aortic homograft

\begin{tabular}{|c|c|c|c|c|c|c|c|c|}
\hline \multirow[t]{2}{*}{ Author } & \multirow{2}{*}{$\begin{array}{c}\text { Total } \\
\text { patients }\end{array}$} & \multirow{2}{*}{$\begin{array}{c}\text { Patients treated with } \\
\text { AH }\end{array}$} & \multirow{2}{*}{$\begin{array}{c}\text { 30-day } \\
\text { mortality (\%) }\end{array}$} & \multirow[t]{2}{*}{ Reinfection (\%) } & \multirow[t]{2}{*}{ SVD (\%) } & \multicolumn{3}{|c|}{ Survival (\%) } \\
\hline & & & & & & 1 year & 5 years & 10 years \\
\hline Perrotta 2015 & 87 PVE & 56 & 10.7 & None & 5.3 & NA & $74 \%$ & $58 \%$ \\
\hline \multirow[t]{3}{*}{ Perrotta 2010} & 62 & 62 & 15 & 1.6 & 1.6 & 82 & 75 & 67 \\
\hline & $31 \mathrm{NVE}$ & & 10 & & & 88 & 79 & 79 \\
\hline & $31 \mathrm{PVE}$ & & 19 & & & 78 & 70 & 51 \\
\hline \multirow[t]{3}{*}{ Musci 2010} & 221 & 221 & 21 & 5.4 & 8.6 & & & \\
\hline & 99 NVE & & 16 & 6 & 11 & 77 & 66 & 47 \\
\hline & 122 PVE & & 25 & 4.9 & 6.5 & 67 & 48 & 35 \\
\hline Lopes 2007 & $41 \mathrm{PVE}$ & 41 & 4.9 & None & 4.8 & 91 & 85 & 79 \\
\hline \multirow[t]{3}{*}{ Grinda 2005} & 104 & 104 & 5 & 5.7 & 5.7 & 93 & 86 & 83 \\
\hline & $76 \mathrm{NVE}$ & & 3 & & & & & \\
\hline & 28 PVE & & 11 & & & & & \\
\hline \multirow[t]{3}{*}{ Yankah 2005} & 161 & 161 & 14 & 6.8 & 1.2 & 75 & 70 & 70 \\
\hline & 80 NVE & & & & & & & \\
\hline & $81 \mathrm{PVE}$ & & & & & & & \\
\hline Leyh 2004 & 29 PVE & 16 & 18.7 & None & None & 81 & 81 & NA \\
\hline Sabik 2002 & 103 PVE & 103 & 3.9 & 3.8 & NA & 90 & 73 & 56 \\
\hline Lytle 2002 & 27 PVE & 27 & 4 & 4 & NA & 92 & 70 & NA \\
\hline \multirow[t]{3}{*}{ Niwaya 1999} & 81 & 46 & 17 & 2.1 & None & NA & 69 & NA \\
\hline & $52 \mathrm{NVE}$ & & & & & & & \\
\hline & 29 PVE & & & & & & & \\
\hline
\end{tabular}

$\mathrm{AH}$ - aortic homograft, NA - not available, NVE - native valve endocarditis, PVE - prosthetic valve endocarditis, SVD - structural valve deterioration

plete resection of all infected tissue, adequate antibiotic treatment, and liberal use of aortic homografts.

Homografts deteriorate progressively and may necessitate reoperation [20]. It has been demonstrated, mainly in patients without endocarditis, that the risk of dysfunction is substantial and higher for homografts than for unstented biological valves [27]. The incidence of structural valve deterioration in patients with IE ranges from $2 \%$ to $8.6 \%[5,20,24]$. However, it should be pointed out that the number of patients who underwent reoperation only reflects the most severe forms of deterioration. Some patients may have severe deterioration of the homograft but are not reoperated on due to their general condition, comorbidity, or age.

However, although homografts may confer a theoretical advantage in resisting infection because of their lack of artificial materials [6], their use is accompanied by a number of potential drawbacks. Homografts have a limited availability and deteriorate progressively once implanted, ensuring that reoperation will eventually be required, and the presence of severe adhesions will make such reoperations technically challenging. Moreover, an irregular base for the proximal suture line can distort a homograft and render it insufficient.

\section{Stentless prosthesis}

Aortic homografts are not always readily available; thus, several authors have suggested the use of stentless prostheses in this clinical scenario. In 2008 Musci et al. [7] reported on the largest series of Dacron-free stentless prostheses implanted in 255 patients with both native and prosthetic aortic endocarditis. He reported an overall reinfection rate of $8.6 \%$, with $83 \%$ freedom from reinfection at 5 years and 5 -year survival of $46 \%$. Furthermore, he did not find a statistically significant difference in survival and freedom from reinfection between patients with NVE and those with PVE ( $p=0.14$ and $p=0.84)$. In 2010, in a series of 221 patients treated with an aortic homograft, the same author [20] reported a reinfection rate of $5.4 \%$ and 10 -year freedom from reoperation and reinfection of $92 \%$ in native and PVE cases. Long-term survival, at 10 years, was better in native than in PVE $(p=0.029)$.

Stentless prostheses seem to offer low reinfection rates, ranging from $3.7 \%$ to $8.6 \%[7,28]$. The low reinfection rates and good hemodynamic values are comparable to those of cryopreserved homografts. The required stentless prosthesis is available at any time and in several sizes, and its specific design allows the application of a variety of surgical techniques. In patients with less extensive aortic root abscess, these valves can be implanted in the subcoronary position, whereas in patients with a more extensive infection, in which the abscess is localized at and above the level of the annulus, the bioprosthesis can be inserted as a total root replacement [8].

\section{Selection of valve substitute}

There is no unanimous consensus regarding the use of aortic homografts and stentless prostheses, and whether or not such prostheses provide incremental benefits over the use of standard prostheses. The issue of graft selection 
in prosthetic and native aortic valve endocarditis has been debated by some authors who have compared the results of patients with IE treated with implantation of an aortic homograft or standard prosthesis [17, 24-26, 29-31] (Tab. II).

The 30-day mortality reported in the literature ranges from $6.7 \%$ to $17 \%$ for patients who were treated with an aortic homograft $[17,29]$ and from $3 \%$ to $23.5 \%$ for those who received conventional prostheses [26, 31]. Long-term survival between the two groups, at 1, 5 and 10 years, does not show significant differences, suggesting that factors other than the prosthetic devices are associated with late mortality. The reinfection rate, in patients with aortic homograft, ranges between 0 and $7 \%$ in the majority of studies [17, 24-26, 30, 31], but higher incidence has been reported [29]. In patients treated with standard prostheses, the incidence of recurrent endocarditis is reported to be generally higher than in patients treated with a homograft [31]. However, a high reinfection rate is reported in both groups [29, 31]. These data were confirmed by Moon et al. [10], who in a large series of 306 patients with left-sided endocarditis reported no significant difference in operative mortality regardless of whether a mechanical, bioprosthetic, or homograft valve was selected $(p>0.74)$, and the overall long-term survival rates were also similar at both 10 years and 20 years $(p>0.27)$. The author could not identify any difference in rate of recurrent or residual endocarditis among the three groups; during the first 5 years it was $2.1 \pm 1.1 \%$ per patientyear in the mechanical valve cohort, $2.3 \pm 0.6 \%$ in those with bioprostheses, and $3.6 \pm 2.5 \%$ in the homograft valve recipients ( $p>0.88$ between groups). It seems that the material, biological versus prosthetic, used for aortic root replacement has no effect on hospital mortality, long-term mortal- ity, or the incidence of recurrent PVE. The implantation of conventional material, when technically feasible, provides a good solution for patients with no anticoagulation contraindications and is associated with a similar outcome to aortic homograft implantation. However, a homograft valve is ideally suited for reconstruction of the aortic root in the presence of an abscess, because it is easier to handle than conventional prostheses and its anterior mitral leaflet can be used to patch the defect created by the resection of the abscess [32]. The type of prosthesis to be implanted should be selected on the basis of the complete clinical picture for a given patient and the availability and hemodynamic performance of a conduit of the appropriate size.

In case of severe destruction of the aortic annulus, a prosthetic material can be used with the condition that the infected area is carefully debrided and the prosthesis is distanced from the focus of the infection; thus, the "translocation" of the valve prosthesis in an aortic tube seems to be a surgical option in these particular settings [33], and in extreme cases heart transplantation can be taken into consideration [34].

\section{Use of composite graft in infective endocarditis}

A mechanical or biological composite graft is an alternative option in patients with extensive root destruction $[12,13,23]$ (Tab. III). In the literature, there are a few articles that report the use of composite grafts in aortic PVE [12, 13, 23]. These authors reported on a limited number of patients with complex aortic PVE who had undergone either Bentall surgery or the Cabrol procedure. They reported 30day mortality between $11 \%$ and $15 \%$, recurrence of infec-

Tab. II. Outcome of patients with aortic valve endocarditis treated with implantation of an aortic homograft or conventional prostheses

\begin{tabular}{|c|c|c|c|c|c|c|c|c|c|}
\hline \multirow[t]{2}{*}{ Author } & \multirow{2}{*}{$\begin{array}{c}\text { Total } \\
\text { patients }\end{array}$} & \multirow{2}{*}{$\begin{array}{c}\text { Valve } \\
\text { implanted }\end{array}$} & \multirow{2}{*}{$\begin{array}{c}\text { 30-day } \\
\text { mortality (\%) }\end{array}$} & \multirow[t]{2}{*}{ Abscess (\%) } & \multirow[t]{2}{*}{ SVD (\%) } & \multirow[t]{2}{*}{ Reinfection (\%) } & \multicolumn{3}{|c|}{ Survival (\%) } \\
\hline & & & & & & & 1 year & 5 years & 10 years \\
\hline \multirow[t]{2}{*}{ Perrotta 2015} & 87 PVE & AH 56 & 10.7 & NA & 5.3 & None & NA & 74 & 58 \\
\hline & & CP 31 & 9.7 & NA & NA & 13 & NA & 87 & 75 \\
\hline \multirow[t]{3}{*}{ Jassar 2011} & 134 & $\mathrm{AH} 36$ & 6.7 & 78 & NA & 17 & 61 & 58 & NA \\
\hline & 44 NVE & BP 55 & 9.7 & 84 & NA & 5 & 65 & 62 & NA \\
\hline & 90 PVE & MP 43 & 5.9 & 84 & NA & 12 & 67 & 58 & NA \\
\hline \multirow[t]{3}{*}{ Leontyev 2011} & 172 & $\mathrm{AH} 13$ & NA & NA & NA & None & 100 & 100 & NA \\
\hline & 96 NVE & BP 141 & NA & NA & NA & NA & 85 & 76 & NA \\
\hline & 76 PVE & MP 18 & NA & NA & NA & NA & 88 & 84 & NA \\
\hline \multirow[t]{2}{*}{ Klieverik 2009} & 138 NVE & $\mathrm{AH} 106$ & 9 & 38 & 4.7 & 6 & 90 & 80 & 69 \\
\hline & & MP 32 & 3 & 19 & & 3 & 93 & 85 & 74 \\
\hline \multirow[t]{3}{*}{ Avierinos 2007} & 127 & $\mathrm{AH} 54$ & 11 & 75 & NA & 7 & 86 & 80 & 43 \\
\hline & 88 NVE & CP 73 & 8 & 30 & 7 & 5 & 79 & 54 & 54 \\
\hline & 39 PVE & & & & & & & & \\
\hline \multirow[t]{3}{*}{ Knosalla 2000} & 65 & $\mathrm{AH} 47$ & 8.5 & 94 & 6 & 2 & 89 & 82 & 82 \\
\hline & NVE 47 & CP 18 & 23.5 & 83 & None & 17 & 65 & 65 & 65 \\
\hline & PVE 18 & & & & & & & & \\
\hline \multirow[t]{3}{*}{ Niwaya 1999} & 81 & $\mathrm{AH} 46$ & 17 & NA & NA & 2 & NA & 69 & NA \\
\hline & 52 NVE & Ross 25 & 12 & NA & NA & 4 & NA & 88 & NA \\
\hline & 29 PVE & CP 10 & 20 & NA & NA & 10 & NA & 29 & NA \\
\hline
\end{tabular}

$\mathrm{AH}$ - aortic homograft, $\mathrm{BP}$ - biological prostheses, $\mathrm{CP}$ - conventional prostheses, $\mathrm{MP}$ - mechanical prostheses, NA - not available, NVE - native valve endocarditis, PVE - prosthetic valve endocarditis, SVD - structural valve deterioration 
Tab. III. Outcome of patients with aortic valve endocarditis treated with implantation of mechanical or biological composite graft

\begin{tabular}{lccccccc} 
Author & Total patients & $\begin{array}{c}\text { Patients treated } \\
\text { with composite }\end{array}$ & $\begin{array}{c}\text { 30-day } \\
\text { mortality (\%) }\end{array}$ & Reinfection (\%) & \multicolumn{3}{c}{ Survival (\%) } \\
\cline { 3 - 8 } Wilbring 2012 & 31 PVE & 31 & 12.3 & None & 80 & 75 years & Near \\
\hline Leyh 2004 & 29 PVE & 13 & 15 & None & 85 & 85 & NA \\
\hline Hagl 2002 & 28 PVE & 28 & 11 & 4 & 81 & 81 & NA \\
\hline
\end{tabular}

NA - not available, PVE - prosthetic valve endocarditis

tion between 0 and $4 \%$, and 5 -year survival between $75 \%$ and $85 \%$. In selected centers, this surgical approach seems to be feasible, and the results are comparable with those from the use of the aortic homograft.

\section{Ross operation in infective endocarditis}

The use of the Ross procedure for the treatment of aortic valve endocarditis has been suggested by some authors $[35,36]$. However, few series specifically report the results of the Ross procedure in aortic native and prosthetic endocarditis. The number of patients treated in these series is limited, and often the data are recorded over several years. The reported hospital mortality ranges from $4.7 \%$ to $12 \%$ $[17,36]$ and the 5 -year survival ranges from $93 \%$ to $88 \%$ [17, 36]. In a recent study [36], the author reported a reinfection rate of $7 \%$ and pulmonary artery stenosis rate of $19 \%$ after a medium follow-up of 10 years. The Ross procedure seems to be feasible and can be safely performed with good midterm results, and it can be considered an alternative to the aortic homograft and prosthetic valves. Due to the limited number of patients treated and the short follow-up, the final judgment of the pulmonary autograft in patients with aortic valve endocarditis remains inconclusive.

The primary motivation for using a Ross operation for patients with aortic endocarditis is to provide a prosthesis that does not require anticoagulation, which have a low risk of re-infection, have good hemodynamic performances and will have a chance of being a permanent solution due to its potential of growth. There is strong criticism of the Ross operation because this surgical technique consists of a double valve replacement for a single valve disease, requires longer cross clamp times, and similar results can be achieved using an aortic homograft. The technique has the risk of development of a homograft stenosis in the right ventricular outflow tract that is inherent in the Ross procedure, and it is considered to be a technically challenging procedure and should be performed by surgeons familiar with the technique.

\section{Eradication of the infection}

Prosthetic infectious endocarditis is a progressive and continuous disease, and its action results in progressive periannular destruction with abscess formation, valve dehiscence, and, consequently, hemodynamic deterioration. Once the diagnosis of aortic valve endocarditis has been established and there is an indication for surgical intervention, surgery should not be delayed [10, 13, 23]. The key to success in the treatment of the disease is radical debridement with resection of all infectious and necrotic tissue, regardless of the cardiac structures involved [32], and prolonged antibiotic therapy [4].

\section{Surgery of the abscess}

The extension to the paravalvular tissue represents the natural evolution of the infection of the valvular cusps in the case of a native valve, or the prosthetic ring in the case of a pre-existing prosthesis. The degree of para-annular involvement is closely linked to the virulence of the microorganism and to the duration of the infection before antibiotic treatment. This condition can lead to valve dehiscence, aortic-to-atrial fistula, left fibrous trigone abscess, or ventricular septal defect.

The ideal surgical treatment of active endocarditis aims to debride the infected tissue regardless of the proximity of the conduction system, to exclude the abscess cavity from the circulation and subsequently from the prosthesis, eliminate all the possible foci of infection, and reconstruct the aortic annulus and the left ventricle outflow tract.

Small annular abscess cavities without perforation into other cardiac chambers can be debrided and filled with antibiotic-impregnated fibrin glue or simply incorporated into the valve fixation sutures [37]. It is reported that fibrin-glue-sealed defects may withstand high burst pressure, but it failed to obliterate perfused cavities in the dead space between the native aortic and the allograft aortic wall [38]. An abscess limited to the aortic annulus and not perforating the aortic wall can be removed by excision of that portion of the annulus and corresponding aortic wall, and the reconstruction of the annulus can be performed with a tailored patch of autologous pericardium [39]. A more extensive resection is needed when the abscess extends through the aortic wall into other tissues or cavities. When the interventricular septum is involved, a radical resection of the infected tissues is performed regardless of the proximity of the conduction system, and the reconstruction can be performed with an autologous pericardial patch. In the presence of mitro-aortic infection with destruction of the left fibrous trigone extension, a complete mitro-aortic monobloc replacement can be performed [40]. 


\section{Study limitations}

The most important limitations of this review are the retrospective study design of the articles analyzed and the limited number of patients included. The retrospective design implies inevitable selection bias, and the limited number of patients implies a pronounced risk for statistical type II errors. The patients were collected over a long period. The diagnostic preoperative assessment of patients with IE differed in the articles, and the patients underwent different surgical techniques performed by different surgeons. Another limitation is that comorbidities, such as stroke and heart failure, may influence the results.

\section{Conclusions}

In aortic valve endocarditis, early surgery should be considered. There is no clear evidence on which is the most appropriate valve substitute in infective endocarditis. The low rate of recurrence of infection is mainly attributed to radical debridement and resection of all infected tissue and prolonged antibiotic therapy. Patients with extreme aortic root destruction and with an aortic root abscess can be more easily treated by implantation of an aortic homograft. Stentless prostheses can be valid alternatives to homografts. However, most anatomic lesions can be treated by annulus reconstruction and aortic root replacement with conventional prostheses. All these devices provide a good solution in terms of survival and recurrent endocarditis. The use of a composite graft is feasible, with results comparable to those of aortic homograft root replacement; however, the procedure is associated with high mortality and morbidity. The Ross procedure seems to be a feasible surgical option, but the limited number of patients treated makes it difficult to give a definitive judgment on its validity. The type of prosthetic device to implant should be selected on the basis of the complete clinical picture for a given patient, including the technical requirements for reconstruction, the patient's age and comorbidities, an assessment of compliance with medication and follow-up, and the availability and hemodynamic performance of a conduit of the appropriate size.

\section{Disclosure}

\section{Authors report no conflict of interest.}

\section{References}

1. Pilmis B, Mizrahi A, Laincer A, Couzigou C, El Helali N, Nguyen Van JC, Abassade P, Cador R, Le Monnier A. Infective endocarditis: clinical presentation, etiology, and early predictors of in-hospital case fatality. Med Mal Infect 2016; 46: 44-48.

2. Thuny F, Grisoli D, Collart F, Habib G, Raoult D. Management of infective endocarditis: challenges and perspectives. Lancet 2012; 379: 965-975.

3. Akowuah EF, Davies W, Oliver S, Stephens J, Riaz I, Zadik P, Cooper G. Prosthetic valve endocarditis: early and late outcome following medical or surgical treatment. Heart 2003; 89: 269-272.

4. Habib G, Lancellotti P, Antunes MJ, Bongiorni MG, Casalta JP, Del Zotti F, Dulgheru R, El Khoury G, Erba PA, lung B, Miro JM, Mulder BJ, Plonska-Gosciniak E, Price S, Roos-Hesselink J, Snygg-Martin U, Thuny F, Tornos Mas P, Vilacosta I, Zamorano JL; Document Reviewers, Erol Ç, Nihoyannopoulos P,
Aboyans V, Agewall S, Athanassopoulos G, Aytekin S, Benzer W, Bueno H, Broekhuizen L, Carerj S, Cosyns B, De Backer J, De Bonis M, Dimopoulos K, Donal E, Drexel H, Flachskampf FA, Hall R, Halvorsen S, Hoen B, Kirchhof P, Lainscak M, Leite-Moreira AF, Lip GY, Mestres CA, Piepoli MF, Punjabi PP, Rapezzi C, Rosenhek R, Siebens K, Tamargo J, Walker DM. 2015 ESC Guidelines for the management of infective endocarditis: The Task Force for the Management of Infective Endocarditis of the European Society of Cardiology (ESC). Endorsed by: European Association for Cardio-Thoracic Surgery (EACTS), the European Association of Nuclear Medicine (EANM). Eur Heart J 2015; 36: 3075-3128.

5. Perrotta S, Aljassim O, Jeppsson A, Bech-Hanssen O, Svensson G. Survival and quality of life after aortic root replacement with homografts in acute endocarditis. Ann Thorac Surg 2010; 90: 1862-1867.

6. Sabik JF, Lytle BW, Blackstone EH, Marullo AG, Pettersson GB, Cosgrove DM. Aortic root replacement with cryopreserved allograft for prosthetic valve endocarditis. Ann Thorac Surg 2002; 74: 650-659; discussion 659.

7. Musci M, Siniawski H, Pasic M, Weng Y, Loforte A, Kosky S, Yankah C, Hetzer R. Surgical therapy in patients with active infective endocarditis: seven-year single centre experience in a subgroup of 255 patients treated with the Shelhigh stentless bioprosthesis. Eur J Cardiothorac Surg 2008; 34: 410-417.

8. Perrotta S, Lentini S. In patients with severe active aortic valve endocarditis, is a stentless valve as good as the homograft? Interact Cardiovasc Thorac Surg 2010; 11: 309-313.

9. Lytle BW, Priest BP, Taylor PC, Loop FD, Sapp SK, Stewart RW, McCarthy PM, Muehrcke D, Cosgrove DM 3rd. Surgical treatment of prosthetic valve endocarditis. J Thorac Cardiovasc Surg 1996; 111: 198-207; discussion 207-210.

10. Moon MR, Miller DC, Moore KA, Oyer PE, Mitchell RS, Robbins RC, Stinson EB, Shumway NE, Reitz BA. Treatment of endocarditis with valve replacement: the question of tissue versus mechanical prosthesis. Ann Thorac Surg 2001; 71: 1164-1171.

11. Musci M, Hübler M, Amiri A, Stein J, Kosky S, Meyer R, Weng Y, Hetzer R. Surgical treatment for active infective prosthetic valve endocarditis: 22-year single-centre experience. Eur J Cardiothorac Surg 2010; 38: 528-538.

12. Wilbring M, Tugtekin SM, Alexiou K, Matschke K, Kappert U. Composite aortic root replacement for complex prosthetic valve endocarditis: initial clinical results and long-term follow-up of high-risk patients. Ann Thorac Surg 2012; 94: 1967-1974.

13. Hagl C, Galla JD, Lansman SL, Fink D, Bodian CA, Spielvogel D, Griepp RB. Replacing the ascending aorta and aortic valve for acute prosthetic valve endocarditis: is using prosthetic material contraindicated? Ann Thorac Surg 2002; 74: S1781-S1785; discussion S1792-S1799.

14. Kirklin JK. Challenging homografts as the holy grail for aortic valve endocarditis. J Thorac Cardiovasc Surg 2016; 151: 1230-1231.

15. Tedoriya T, Okano R, Kamiya K, Maeba S, Fukuzumi M. Management for active infective endocarditis with extensive aortic root abscess. J Cardiothorac Surg 2015; 10 Suppl 1: A212.

16. Von Eiff C, Peters G, Heilmann C. Pathogenesis of infections due to coagulase-negative staphylococci. Lancet Infect Dis 2002; 2: 677-685.

17. Niwaya K, Knott-Craig CJ, Santangelo K, Lane MM, Chandrasekaran K, Elkins RC. Advantage of autograft and homograft valve replacement for complex aortic valve endocarditis. Ann Thorac Surg 1999; 67: 1603-1608.

18. Yankah AC, Pasic M, Klose H, Siniawski H, Weng Y, Hetzer R. Homograft reconstruction of the aortic root for endocarditis with periannular abscess: a 17-year study. Eur J Cardiothorac Surg 2005; 28: 69-75.

19. Grinda JM, Mainardi JL, D’Attellis N, Bricourt MO, Berrebi A, Fabiani JN, Deloche A. Cryopreserved aortic viable homograft for active aortic endocarditis. Ann Thorac Surg 2005; 79: 767-771.

20. Musci M, Weng Y, Hübler M, Amiri A, Pasic M, Kosky S, Stein J, Siniawski H, Hetzer R. Homograft aortic root replacement in native or prosthetic active infective endocarditis: twenty-year single-center experience. J Thorac Cardiovasc Surg 2010; 139: 665-673.

21. Lytle BW, Sabik JF, Blackstone EH, Svensson LG, Pettersson GB, Cosgrove DM 3rd. Reoperative cryopreserved root and ascending aorta replacement for acute aortic prosthetic valve endocarditis. Ann Thorac Surg 2002; 74: S1754-S1757; discussion S1792-S1799.

22. Lopes S, Calvinho P, de Oliveira F, Antunes M. Allograft aortic root replacement in complex prosthetic endocarditis. Eur J Cardiothorac Surg 2007; 32: 126-130; discussion 131-132.

23. Leyh RG, Knobloch K, Hagl C, Ruhparwar A, Fischer S, Kofidis T, Haverich A. Replacement of the aortic root for acute prosthetic valve endocarditis: prosthetic composite versus aortic allograft root replacement. J Thorac Cardiovasc Surg 2004; 127: 1416-1420. 
24. Perrotta S, Jeppsson A, Fröjd V, Svensson G. Surgical treatment of aortic prosthetic valve endocarditis: a 20-year single-center experience. Ann Thorac Surg 2016; 101: 1426-1432.

25. Avierinos JF, Thuny F, Chalvignac V, Giorgi R, Tafanelli L, Casalta JP, Raoult D, Mesana T, Collart F, Metras D, Habib G, Riberi A. Surgical treatment of active aortic endocarditis: homografts are not the cornerstone of outcome. Ann Thorac Surg 2007; 84: 1935-1942.

26. Klieverik LM, Yacoub MH, Edwards S, Bekkers JA, Roos-Hesselink JW, Kappetein AP, Takkenberg JJ, Bogers AJ. Surgical treatment of active native aortic valve endocarditis with allografts and mechanical prostheses. Ann Thorac Surg 2009; 88: 1814-1821.

27. El-Hamamsy I, Clark L, Stevens LM, Sarang Z, Melina G, Takkenberg JJ, Ya coub $\mathrm{MH}$. Late outcomes following freestyle versus homograft aortic root replacement: results from a prospective randomized trial. J Am Coll Cardiol 2010; 55: 368-376

28. Siniawski H, Grauhan O, Hofmann M, Pasic M, Weng Y, Yankah C, Lehmkuhl $\mathrm{H}$, Hetzer R. Aortic root abscess and secondary infective mitral valve disease: results of surgical endocarditis treatment. Eur J Cardiothorac Surg 2005; 27: 434-440.

29. Jassar AS, Bavaria JE, Szeto WY, Moeller PJ, Maniaci J, Milewski RK, Gorman JH 3rd, Desai ND, Gorman RC, Pochettino A. Graft selection for aortic root replacement in complex active endocarditis: does it matter? Ann Thorac Surg 2012; 93: 480-487.

30. Leontyev S, Borger MA, Modi P, Lehmann S, Seeburger J, Doenst T, Mohr FW. Surgical management of aortic root abscess: a 13-year experience in 172 patients with 100\% follow-up. J Thorac Cardiovasc Surg 2012; 143: 332-337.

31. Knosalla C, Weng Y, Yankah AC, Siniawski H, Hofmeister J, Hammerschmidt R, Loebe M, Hetzer R. Surgical treatment of active infective aortic valve endocarditis with associated periannular abscess - 11 year results. Eur Heart J 2000; 21: 490-497
32. David TE, Gavra G, Feindel CM, Regesta T, Armstrong S, Maganti MD. Surgical treatment of active infective endocarditis: a continued challenge. J Thorac Cardiovasc Surg 2007; 133: 144-149.

33. Stamou SC, Murphy MC, Kouchoukos NT. Left ventricular outflow tract reconstruction and translocation of the aortic valve for annular erosion: early and midterm outcomes. J Thorac Cardiovasc Surg 2011; 142: 292-297.

34. Valencia Nuńez DM, Merino Cejas C, Alados Arboledas P, Muńoz Carvajal I. Heart transplantation in a patient with recurrent early extensive endocarditis. Interact Cardiovasc Thorac Surg 2013; 17: 423-425.

35. David TE, Woo A, Armstrong S, Maganti M. When is the Ross operation a good option to treat aortic valve disease? J Thorac Cardiovasc Surg 2010; 139: 68-73.

36. Ringle A, Richardson M, Juthier F, Rousse N, Polge AS, Coisne A, Duva-Pentiah A, Ben Abda A, Banfi C, Montaigne D, Vincentelli A, Prat A. Ross procedure is a safe treatment option for aortic valve endocarditis: long-term follow-up of 42 patients. Int J Cardiol 2015; 203: 62-68.

37. Farhat $F$, Durand $M$, Delahaye $F$, Jegaden O. Prosthetic valve sewing-ring sealing with antibiotic and fibrin glue in infective endocarditis. A prospective clinical study. Interact Cardiovasc Thorac Surg 2007; 6: 16-20.

38. von Segesser LK, Fasnacht MS, Vogt PR, Genoni M, Arbenz U, Turina MI. Prevention of residual ventricular septal defects with fibrin sealant. Ann Thorac Surg 1995; 60: 511-516.

39. David TE. The surgical treatment of patients with prosthetic valve endocarditis. Semin Thorac Cardiovasc Surg 1995; 7: 47-53.

40. Obadia JF, Henaine R, Bergerot C, Ginon I, Nataf P, Chavanis N, Robin J, Andre-Fouet X, Ninet J, Raisky O. Monobloc aorto-mitral homograft or mechanical valve replacement: a new surgical option for extensive bivalvular endocarditis. J Thorac Cardiovasc Surg 2006; 131: 243-245. 